\title{
Pengaruh Leverage dan Ukuran Perusahaan Terhadap Profitabilitas Dengan Modal Intelektual sebagai Pemoderasi
}

\author{
Ni Luh Meili Andreani ${ }^{1}$ \\ I Made Pande Dwiana Putra ${ }^{2}$ \\ ${ }^{1,2}$ Fakultas Ekonomi dan Bisnis Universitas Udayana (Unud), Bali, Indonesia \\ e-mail: andreanimeili@gmail.com
}

\begin{abstract}
ABSTRAK
Penelitian ini bertujuan untuk menganalisis pengaruh leverage dan ukuran perusahaan terhadap profitabilitas dengan modal intelektual sebagai pemoderasi. Penelitian ini dilakukan pada perusahaan sub sektor tekstil dan garmen yang terdaftar di Bursa Efek Indonesia tahun 2015-2017. Sampel diambil dengan menggunakan teknik sampling jenuh, jadi seluruh populasi dijadikan sampel sebanyak 11 perusahaan. Terdapat 33 sampel dari tiga tahun amatan penelitian. Hasil penelitian menunjukkan bahwa leverage berpengaruh negatif terhadap profitabilitas. Hal ini menunjukkan bahwa penggunaan utang akan berisiko terjadinya kesulitan keuangan. Modal intelektual memperlemah pengaruh leverage terhadap profitabilitas. Hal ini menunjukkan bahwa perusahaan harus memperhatikan pengelolaan sumber daya yaitu peningkatan kompetensi, kemampuan, keterampilan (skill) dan pengetahuan karyawan akan memberikan kontribusi dalam pengelolaan utang sehingga mampu meningkatkan profitabilitas perusahaan.
\end{abstract}

Kata kunci: Modal intelektual, leverage, ukuran perusahaan, profitabilitas.

\begin{abstract}
This study aims to analyze the effect of leverage and firm size on profitability with intellectual capital as a moderator. This research was conducted on textile and garment sub-sector companies listed on the Indonesia Stock Exchange in 2015-2017. Samples were taken using saturated sampling techniques, so the entire population was sampled as many as 11 companies. There were 33 samples from three years of research observations. The results show that leverage has a negative effect on profitability. This shows that the use of debt will risk the occurrence of financial difficulties. Intellectual capital weakens the influence of leverage on profitability. This shows that the company must pay attention to resource management, namely increasing competence, ability, skills (knowledge) and knowledge of employees will contribute to debt management so as to increase the profitability of the company.
\end{abstract}

Keywords: Intellectual capital, leverage, company size, profitability.

\section{PENDAHULUAN}

Perkembangan globalisasi menekankan pentingnya keunggulan kompetitif yang berkelanjutan. Perusahaan harus memiliki daya saing berbasis pengetahuan dengan pengelolaan modal intelektual untuk menciptakan nilai. Modal Intelektual merupakan komponen yang digunakan oleh perusahaan untuk menghasilkan nilai 
aset yang lebih tinggi. Williams (2001), mendefinisikan modal intelektual sebagai informasi dan pengetahuan yang diaplikasikan dalam pekerjaan untuk menciptakan nilai. Pernyataan Standar Akuntansi Keuangan (PSAK) No. 19 tentang aktiva tidak berwujud adalah aktiva non-moneter yang dapat diidentifikasi dan tidak mempunyai wujud fisik yang akan digunakan dalam menghasilkan atau menyerahkan barang atau jasa, disewakan kepada pihak lainnya, atau untuk tujuan administratif. PSAK No. 19 revisi tahun 2015 tentang aktiva tidak berwujud sudah mulai menimbulkan fenomena tentang modal intelektual di Indonesia yang semakin berkembang, walaupun tidak secara eksplisit dijelaskan tentang modal intelektual.

Stewart (2003) menyatakan bahwa perusahaan-perusahaan di Indonesia cenderung menggunakan praktik akuntansi tradisional yaitu praktik akuntansi yang berdasarkan sumber daya alam, sumber daya modal, dan aktiva fisik lainnya dalam menjalankan bisnis, sehingga produk yang dihasilkan belum maksimal terhadap implementasi pengetahuan. Praktik akuntansi tradisional fokus pada pengendaliaan biaya, sedangkan akuntansi modern fokus pada penciptaan nilai. Tujuan utama dalam bisnis yang berbasis pengetahuan adalah untuk menciptakan nilai tambah (value added). Penelitian terdahulu menyatakan bahwa keuntungan berkelanjutan bergantung dalam mengelola modal intelektual yaitu sumber daya intangible (Johanson et al., 1999). Pengetahuan dapat membantu perusahaan dalam meningkatkan penjualan produk dan melakukan aktivitas bisnis yang lebih efisien (WTC of London, 1998). Kesuksesan perusahaan ditentukan oleh keunggulan kompetitif yang diperoleh dari pengelolaan modal intelektual secara 
efektif (Hurwitz et al., 2002). Pengetahuan terhadap pengelolaan sumber daya, baik itu sumber daya alam, sumber daya manusia dan sumber daya modal bila diterapkan secara efektif dan efisien akan mempengaruhi tingkat pencapaian keuntungan. Semakin baik pengelolaan terhadap sumber daya tersebut, maka semakin tinggi keuntungan perusahaan.

Tekstil dan garmen merupakan industri yang menghasilkan pakaian jadi yang merupakan kebutuhan pokok yaitu sandang. Produk yang dihasilkan dari industri tekstil dan garmen sangat penting bagi masyarakat. Industri tekstil dan garmen dalam perekonomian Indonesia memiliki peran yang cukup signifikan. Industri ini memiliki potensi pertumbuhan yang cukup besar, dengan sumber daya alam yang memadai, serta tersedianya tenaga kerja dalam jumlah besar. Industri tekstil dan garmen merupakan salah satu kelompok industri yang termasuk industri prioritas berdasarkan Perpres Nomor 28 Tahun 2008 tentang Kebijakan Industri Nasional (Efendi, 2013), tetapi kinerja dari industri ini belum memuaskan. Hal ini tercermin dari pertumbuhan laba yang tidak stabil dari perusahaan-perusahaan yang bergerak di industri ini.

Daya saing industri tekstil dan garmen Indonesia dengan negara lain masih rendah. Negara Cina mampu memproduksi produk jadi dalam jumlah banyak dan beragam dengan biaya yang lebih rendah. Pangsa pasar untuk tekstil dan garmen masih dikuasai oleh negara Cina. Produk jadi di Indonesia belum bisa menyaingi produk Cina, dari segi kualitas seperti mudah luntur, mudah berkerut dan tidak nyaman dalam penggunaan. Intervensi produk Cina menyebabkan industri tekstil dan garmen dalam negeri kehilangan pasar. 
Ni Luh Meili Andreani dan I Made Pande Dwiana Putra. Pengaruh ...

Berikut ini sebuah artikel yang menceritakan bagaimana perusahaan sub sektor tekstil dan garmen dalam impor dan ekspor. Data dari Kementerian Perindustrian, impor bahan baku tekstil pada tahun 2015 tercatat sebesar US\$ 6,7 miliar, meningkat dari tahun 2014 sebesar US\$ 6,51 miliar. Sepanjang tahun 2016, jumlah kain impor tercatat hampir 700.000 ton, sedangkan industri hulu tekstil mengekspor kain sebesar 500.000 ton. Impor bahan baku tekstil tersebut antara lain sutra, serat tekstil, serat stapel, benang filamen, benang tenunan, benang rajutan, sulaman atau bordir, dan kain lainnya. Sementara itu, impor tahun 2017 yakni sebesar US\$ 1,38 miliar yakni lebih rendah. Sementara untuk impor produk pakaian jadi tahun 2016 tercatat sebesar US\$ 436,33 juta, atau naik 4,39\% dibandingkan tahun 2015 yakni US\$ 421,61 juta. Impor pakaian jadi di tahun 2017 sebesar US\$ 77,53 juta atau naik 2,39\% dibandingkan periode yang sama tahun 2016 sebesar US\$ 75,72 juta (www.finance.detik.com).

Berdasarkan data dari tahun 2015-2017 perusahaan yang bergerak dibidang tekstil dan garmen memiliki tingkat pencapaian keuntungan yang tidak stabil.

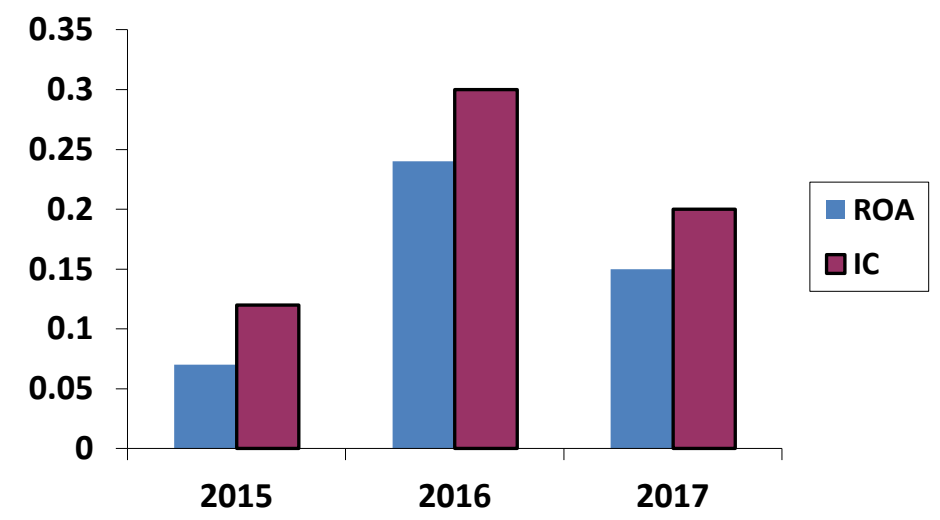

Gambar 1.

Rata-rata Perbandingan Pertumbuhan Laba dan Modal Intelektual pada Sub Sektor Tekstil dan Garmen periode 2015-2017

Sumber : www.idx.co.id, 2018 
Gambar 1 menunjukkan bahwa perusahaan sub sektor tekstil dan garmen memiliki pertumbuhan laba yang tidak stabil dan disertai modal intelektual. Semakin tinggi modal intelektual maka profitabilitas juga semakin meningkat. Tahun 2015 kinerja perusahaan sub sektor tekstil dan garmen terendah 7\% dengan modal intelektual sebesar 12\%. Pada tahun 2016 kinerja perusahaan meningkat menjadi 24\% dengan modal intelektual sebesar 31\% dan di tahun 2017 kembali mengalami penurunan yaitu kinerja perusahaan $14 \%$ dan modal intelektual sebesar 20\%. Hal ini menunjukkan bahwa kinerja perusahaan belum memuaskan. Organisasi yang menerapkan manajemen pengetahuan (knowledge management), maka kemakmuran suatu perusahaan akan bergantung pada penciptaan transformasi dan kapitalisasi dari pengetahuan itu sendiri (Sawarjuwono \& Kadir, 2003). Profitabilitas pada perusahaan sub sektor tekstil dan garmen juga dapat dipengaruhi oleh leverage dan faktor-faktor lainnya.

Perusahaan dalam menjalankan operasional menggunakan dana yang besar, baik dana yang berasal dari perusahaan dan dana yang berasal dari pihak ketiga. Trade-off theory merupakan teori yang menjelaskan keseimbangan antara manfaat dan pengorbanan dalam penggunaan utang (Brigham dan Houston, 2011). Teori ini menjelaskan apabila manfaat yang diterima lebih besar daripada pengorbanan, maka perusahaan akan menambah jumlah utang. Sebaliknya, apabila manfaat yang diterima lebih kecil dari pengorbanan, maka perusahaan tidak menambah jumlah utang. Trade-off theory merupakan teori yang menjelaskan keseimbangan antara manfaat dan pengorbanan dalam penggunaan utang (Brigham dan Houston, 2011). Teori ini menjelaskan apabila manfaat yang diterima lebih besar daripada 
pengorbanan, maka perusahaan akan menambah jumlah utang. Sebaliknya, apabila manfaat yang diterima lebih kecil dari pengorbanan, maka perusahaan tidak menambah jumlah utang. Dalam hal ini, perusahaan menganalisis leverage dengan debt to total asset. Semakin tinggi proporsi utang suatu perusahaan maka semakin tinggi harga saham perusahaan itu, namun pada titik tertentu lainnya peningkatan utang akan menurunkan nilai perusahaan (Chen dan Steiner, 1999). Biaya bunga yang timbul dari penggunaan utang akan mengurangi profitabilitas perusahaan. Ketika tarif pajak lebih besar daripada suku bunga bank, maka penggunaan utang akan berdampak positif pada profitabilitas, apabila sebaliknya yaitu tarif pajak lebih kecil dari suku bunga bank, maka penggunaan utang dalam jumlah besar akan berdampak negatif pada profitabilitas.

Peningkatan utang akan mempengaruhi besar kecilnya profitabilitas perusahaan. Semakin tinggi utang perusahaan maka kemampuan perusahaan dalam menghasilkan laba akan semakin rendah, karena perusahaan lebih memprioritaskan pembayaran utang daripada profitabilitas. Penelitian yang dilakukan oleh Ritonga et al. (2014) serta Dwipayana \& Suaryana (2016) menyatakan bahwa leverage berpengaruh positif terhadap profitabilitas perusahaan, karena tingkat pengembalian terhadap laba operasional perusahaan lebih besar daripada beban yang timbul akibat penggunaan utang. Peningkatan utang akan meningkatkan profitabilitas perusahaan karena beban bunga yang diperoleh akan dapat menghemat pembayaran pajak, sehingga keuntungan perusahaan tinggi. Penelitian yang dilakukan oleh Supardi et al. (2016) dan Barus \& Leliani (2013) menyatakan debt to asset ratio berpengaruh negatif 
terhadap profitabilitas, karena beban tetap yang timbul akibat penggunaan utang yang lebih besar daripada manfaat yang diperoleh sehingga menimbulkan kesulitan keuangan dan profitabilitas perusahaan menurun.

Ukuran perusahaan juga dapat mempengaruhi tingkat profitabilitas. Besar kecilnya perusahaan akan mempengaruhi kemampuan perusahaan dalam menanggung risiko yang mungkin timbul dari berbagai situasi yang dihadapi perusahaan (Ariyanto, 2002). Menurut Hartono M. (2000), perbedaan ukuran perusahaan menimbulkan risiko usaha yang berbeda secara signifikan antara perusahaan besar dan perusahaan kecil, mereka juga merumuskan perusahaan yang besar dianggap mempunyai risiko yang lebih kecil, karena perusahaan yang besar dianggap lebih mempunyai akses ke pasar modal sehingga lebih mudah untuk mendapatkan tambahan dana yang kemudian dapat meningkatkan profitabilitas perusahaan. Perusahaan besar belum tentu memiliki peluang untuk memperoleh laba yang tinggi karena biaya operasional perusahaan juga tinggi. Ketika perusahaan ada di tahap bertumbuh (growth), maka perusahaan tersebut memiliki peluang besar untuk menghasilkan laba yang tinggi karena biaya operasional cenderung tidak terlalu tinggi. Perusahaan yang ada di tahap dewasa (mature), cenderung mengalami penurunan profitabilitas karena biaya operasional yang tinggi dan pengelolaan aset yang belum efektif dan efisien.

Penelitian yang dilakukan oleh Amato \& Wilder (2015) serta Lee (2009) menyatakan bahwa ukuran perusahaan berpengaruh positif terhadap profitabilitas, karena perusahaan besar lebih mudah untuk memperoleh modal untuk kebutuhan memperluas usahanya (ekspansi), selain itu SDM yang dimiliki perusahaan besar 
lebih kompeten daripada perusahaan kecil. Berbeda dengan penelitian yang dilakukan oleh Miyanti \& Putra (2010) serta Ratnasari (2016) yaitu ukuran perusahaan berpengaruh negatif terhadap profitabilitas, karena pada perusahaan besar yang belum berani dalam memperluas usahanya dengan ekspansi, maka ia cenderung memiliki profitabilitas yang tidak terlalu tinggi.

Perusahaan agar mampu going concern dalam persaingan antar perusahaan, menuntut perusahaan memiliki keunggulan kompetitif. Menurut Peteraf (1993) dan Wernerfelt (1984), bahwa untuk membangun keunggulan kompetitif yang berkelanjutan untuk mempertahankan profitabilitas di atas rata-rata mengharuskan perusahaan untuk menciptakan dan memelihara sumber daya strategis. Grant (1997) menyatakan resource-based theory adalah teori yang menjelaskan bahwa sumber daya sangat penting dalam memberikan nilai tambah, salah satunya adalah pengetahuan. Menurut teori ini, apabila modal intelektual dapat dikelola dan dikembangkan dengan baik, maka perusahaan dapat efisien dalam mengelola aset perusahaan sehingga profitabilitas perusahaan akan meningkat dan menghasilkan keunggulan kompetitif bagi perusahaan.

Populasi pada penelitian ini adalah mengambil perusahaan sub sektor tekstil dan garmen yang ada di Bursa Efek Indonesia tahun 2015-2017. Selama beberapa tahun terakhir profitabilitas pada perusahaan sub sektor tekstil dan garmen tidak stabil. Sebagian besar pangsa pasar dikuasai oleh negara asing, seperti produk tekstil buatan Cina yang akan berdampak pada operasional perusahaan dalam negeri. Industri tekstil dan garmen di Cina mendominasi pangsa 
pasar dunia, karena mampu memproduksi dengan biaya yang lebih rendah, beragam dan lebih cepat.

Penelitian tentang profitabilitas memang telah banyak dilakukan, seperti penelitian yang dilakukan oleh Ritonga et al. (2014) serta Winahyu \& Mimba (2018) menyatakan bahwa leverage berpengaruh positif terhadap profitabilitas perusahaan. Penelitian yang dilakukan oleh Supardi et al. (2016) dan Barus \& Leliani (2013) menyatakan debt to asset ratio berpengaruh negatif terhadap profitabilitas. Penelitian yang dilakukan oleh Amato \& Wilder (2015) serta Lee (2009) menyatakan bahwa ukuran perusahaan berpengaruh positif terhadap profitabilitas. Berbeda dengan penelitian yang dilakukan oleh Miyanti \& Putra (2010) serta Ratnasari (2016) yaitu ukuran perusahaan berpengaruh negatif terhadap profitabilitas. Adanya ketidakkonsistenan hasil penelitian menyebabkan peneliti menduga terdapat variabel yang memperkuat dan memperlemah hubungan leverage dan ukuran perusahaan pada profitabilitas yaitu modal intelektual.

Leverage merupakan rasio yang mengukur besarnya modal perusahaan yang dibiayai dengan utang. Menurut Harahap (2013), leverage adalah rasio yang menggambarkan hubungan antara utang perusahaan terhadap modal, rasio ini dapat melihat seberapa jauh perusahaan dibiayai oleh utang atau pihak ketiga dengan kemampuan perusahaan yang digambarkan oleh modal. Perusahaan yang dana internalnya tidak mencukupi, maka perusahaan akan melakukan pendanaan eksternal yaitu utang. Leverage perusahaan akan berpengaruh terhadap kemampuan perusahaan dalam menghasilkan laba. 
Teori Trade-off menjelaskan keseimbangan antara manfaat dan pengorbanan dalam penggunaan utang (Brigham dan Houston, 2011). Semakin tinggi tingkat utang, maka beban tetap semakin besar sehingga akan berisiko terhadap kesulitan keuangan. Penelitian yang dilakukan oleh Supardi (2016) dan Andreani (2013) menyatakan debt to asset ratio berpengaruh negatif terhadap profitabilitas. Penelitian yang juga dilakukan oleh Sarjana (2013) serta Riaz (2015), menyatakan bahwa variabel debt to asset ratio berpengaruh negatif terhadap profitabilitas. Berdasarkan uraian tersebut, maka dapat dirumuskan hipotesis sebagai berikut. $\mathrm{H}_{1}$ : Leverage berpengaruh negatif pada Profitabilitas.

Perusahaan besar cenderung mudah mendapatkan pinjaman dari kreditur karena perusahaan yang besar memiliki profitabilitas yang tinggi. Semakin besar ukuran suatu perusahaan, maka kecenderungan menggunakan modal asing juga semakin besar. Hal ini disebabkan karena perusahaan besar membutuhkan dana yang besar pula untuk menunjang operasionalnya, dan salah satu alternatif pemenuhannya adalah dengan modal asing apabila modal sendiri tidak mencukupi (Halim, 2007). Perusahaan yang bertumbuh secara signifikan merupakan perusahaan yang lebih besar karena perusahaan yang besar dianggap lebih mempunyai akses ke pasar modal sehingga lebih mudah untuk mendapatkan tambahan dana yang kemudian dapat meningkatkan profitabilitas (Elton dan Gruber, 1994 dalam Hartono M., 2000).

Berdasarkan teori critical resources, semakin besar ukuran perusahaan maka kemampuan perusahaan dalam memperoleh laba juga semakin meningkat, tetapi pada jumlah tertentu ukuran perusahaan akan menurunkan laba perusahaan 
(Kusuma, 2005). Penelitian Niresh \& Velnampy (2014) serta Pratama \& Wiksuana (2016) menyatakan bahwa ukuran perusahaan berpengaruh positif terhadap profitabilitas. Penelitian yang juga dilakukan oleh Lee (2009) juga menyatakan bahwa ukuran perusahaan memiliki dampak positif terhadap profitabilitas. Berdasarkan uraian tersebut, maka dapat dirumuskan hipotesis penelitian sebagai berikut.

$\mathrm{H}_{2}$ : Ukuran Perusahaan berpengaruh positif terhadap Profitabilitas.

Perusahaan tidak lepas dari pendanaan eksternal (utang) dalam menjalankan operasionalnya. Manajer harus tetap menjaga profitabilitas perusahaan dengan menggunakan sumber daya modal yang efektif dan efisien. Pengelolaan utang sangat berpengaruh terhadap keuntungan perusahaan, apabila utang dikelola dengan efektif maka akan memberikan keuntungan, akan tetapi utang yang dikelola dengan tidak efektif akan menimbulkan kesulitan keuangan.

Grant (1997) menyatakan resource-based theory adalah teori yang menjelaskan bahwa sumber daya sangat penting dalam memberikan nilai tambah, salah satunya adalah pengetahuan. Teori ini menjelaskan bagaimana perusahaan mengelola organisasi berbasis pengetahuan yaitu dengan modal intelektual. Pengelolaan utang perlu didasarkan atas pengetahuan strategis antara manfaat dan biaya yang timbul (Grant, 1997). Organisasi yang menerapkan manajemen pengetahuan (knowledge management), maka kemakmuran suatu perusahaan akan bergantung pada penciptaan transformasi dan kapitalisasi dari pengetahuan itu sendiri (Sawarjuwono \& Kadir, 2003). 
Secara umum, semakin tinggi tingkat pengunaan utang maka profitabilitas perusahaan menurun karena berisiko terjadinya financial distress. Pada kondisi, dimana pengunaan utang tinggi dan disertai modal intelektual tinggi maka profitabilitas perusahaan tidak serendah sebelumnya atau dengan kata lain profitabilitas perusahaan lebih baik dari sebelumnya. Hal ini dikarenakan, pengelolaan utang yang didasarkan atas modal intelektual dapat menimbulkan manfaat yang lebih besar dari biaya bunga yang dihasilkan oleh utang tersebut. Berdasarkan uraian tersebut, maka dapat dirumuskan hipotesis penelitian sebagai berikut.

$\mathrm{H}_{3}$ : Modal Intelektual memperlemah pengaruh Leverage terhadap Profitabilitas.

Bhayani (2010) berpendapat bahwa aspek yang menarik dari pertumbuhan ekonomi adalah ukuran organisasi. Perusahaan besar cenderung menggunakan dana eksternal yang lebih besar dari perusahaan kecil serta memiliki fleksibilitas untuk memperoleh dana dari pasar modal. Perusahaan besar dengan manajemen yang lebih baik menyebabkan perusahaan besar mudah memperoleh modal untuk operasional perusahaannya yang kemudian berpengaruh terhadap profitabilitas perusahaan. Perusahaan harus mampu mengelola organisasinya dengan pengetahuan agar efektif dan efisien.

Serrasqueiro \& Nunes (2008) menyatakan hubungan antara ukuran perusahaan dan profitabilitas memiliki hubungan positif dan signifikan. Resource-based theory menjelaskan bahwa membangun keunggulan kompetitif yang berkelanjutan untuk mempertahankan profitabilitas di atas rata-rata mengharuskan perusahaan untuk menciptakan dan memelihara sumber daya 
strategis (Peteraf, 1993). Teori ini menjelaskan bahwa bagaimana perusahaan menggunakan modal intelektualnya untuk menciptakan nilai. Salah satu modal intelektual yang erat kaitannya dengan ukuran perusahaan adalah kompetensi karyawan.

Secara umum, perusahaan yang besar memiliki jumlah karyawan yang banyak. Semakin banyak karyawan yang berkompeten dalam suatu organisasi maka akan semakin meningkat keuntungan perusahaan. Pada kondisi dimana skala perusahaan besar yang disertai dengan modal intelektual yang tinggi maka profitabilitas perusahaan akan lebih tinggi daripada tanpa modal intelektual yang memadai. Hal ini dikarenakan, sumber daya manusia yang kompeten, pengelolaan aset yang efektif dan penggunaan teknologi yang memadai akan meningkatkan produktivitas, sehingga menambah keuntungan perusahaan. Penelitian yang telah dilakukan oleh Winahyu \& Mimba (2018), menyatakan bahwa intellectual capital memperkuat pengaruh ukuran perusahaan terhadap profitabilitas. Berdasarkan uraian tersebut, maka dapat dirumuskan hipotesis penelitian sebagai berikut:

$\mathrm{H}_{4}$ : Modal Intelektual memperkuat pengaruh Ukuran Perusahaan terhadap Profitabilitas.

\section{METODE PENELITIAN}

Penelitian ini diambil dari perusahaan yang terdaftar di Bursa Efek Indonesia (BEI) yang diakses pada www.idx.co.id, www.finance.yahoo.com dan website perusahaan. Obyek dalam penelitian ini adalah pengaruh leverage dan ukuran perusahaan pada profitabilitas perusahaan dengan modal intelektual sebagai 
Ni Luh Meili Andreani dan I Made Pande Dwiana Putra. Pengaruh ...

pemoderasi. Penelitian ini mengambil sampel perusahaan sub sektor tekstil dan garmen yang ada di Bursa Efek Indonesia yang laporan keuangan dilaporkan secara berkala pada tahun 2015-2017.

Variabel profitabilitas (Y) dihitung dengan return on asset (ROA) yaitu rasio yang menunjukkan return atas penggunaan aset dalam menghasilkan laba bersih perusahaan.

$$
\operatorname{ROA}(\mathrm{Y})=\frac{\text { Laba Bersih Setelah Pajak }}{\text { Total Aset }}
$$

Dalam penelitian ini akan menggunakan debt to total asset yaitu rasio yang digunakan untuk mengukur perbandingan antara total utang dengan total aset. Rasio tersebut dapat dirumuskan sebagai berikut :

Debt to Total Asset (X1) $=\frac{\text { Total Utang }}{\text { Total Aset }}$

Kriteria yang pasti mengenai ukuran suatu perusahaan dalam teori critical resources, digunakan rumus :

Firm Size $(\mathrm{X} 2)=$ Ln Total Assets

Dalam penelitian ini menggunakan variabel moderasi yaitu modal intelektual. Modal Intelektual diukur dengan metode Value Added Intellectual Capital (VAIC) yang dikembangkan oleh Pulic tahun 1998. Pemilihan model VAIC sebagai ukuran atas modal intelektual mengacu pada penelitian Winahyu \& Mimba (2018), serta Yuniasih (2011). Formulasi perhitungan VAIC terdiri dari beberapa tahapan sebagai berikut :

$$
\mathrm{VA}=\text { Output }- \text { Input }
$$

Keterangan.

Output $\quad$ : total penjualan dan pendapatan lain-lain 
Input : total beban kecuali beban karyawan.

VACA $=\frac{\text { Value Added }}{\text { Capital Employed }}$

Keterangan :

Value Added : selisih antara output dan input.

Capital Employed : dana yang tersedia (Ekuitas).

VAHU $=\frac{\text { Value Added }}{\text { Human Capital }}$

Keterangan :

Value Added : selisih antara output dan input

Human Capital : beban karyawan

STVA $=\frac{\text { Structural Capital }}{\text { Value Added }}$

Keterangan :

Structural Capital : Value Added-Human Capital

Value Added : selisih antara output dan input

Berdasarkan keempat tahapan di atas, maka VAIC dirumuskan sebagai berikut :

VAIC $(Z)=$ VACA + VAHU + STVA

Populasi dalam penelitian ini adalah seluruh perusahaan sub sektor tekstil dan garmen yang terdaftar di Bursa Efek Indonesia selama periode tahun 20152017 yang berjumlah 11 perusahaan. Dalam penelitian ini teknik pengambilan sampling yang digunakan adalah teknik sampling jenuh. Menurut Sugiyono (2017) sampling jenuh adalah teknik penentuan sampel bila semua anggota populasi digunakan sebagai sampel. Berikut data sampel yang digunakan sebagai berikut: 
Tabel 1.

Daftar Sampel Perusahaan Sub Sektor Tekstil dan Garmen

\begin{tabular}{ccl}
\hline No & Kode Perusahaan & Nama Perusahaan \\
\hline 1 & ARGO & PT. Argo Pantes, Tbk \\
2 & CNTX & PT. Century Textile Indutry, Tbk \\
3 & ESTI & PT. Ever Shine Textile, Tbk \\
4 & INDR & PT. Indorama Synthetics, Tbk \\
5 & PBRX & PT. Pan Brothers, Tbk \\
6 & RICY & PT. Ricky Putra Globalindo, Tbk \\
7 & SRIL & PT. Sri Rejeki Isman, Tbk \\
8 & STAR & PT. Star Petrochem \\
9 & SSTM & PT. Sunson Textile Manufacturer, Tbk \\
10 & TFCO & PT. Tifico Fiber Indonesia, Tbk \\
11 & TRIS & PT. Trisula International, Tbk \\
\hline
\end{tabular}

Sumber: www.idx.co.id, 2018

Teknik analisis yang digunakan dalam penelitian ini ada 2 yaitu analisis regresi majemuk dan moderated regression analysis (MRA) yang diolah dengan bantuan program SPSS. Model regresi dalam penelitian ini ditunjukkan dengan persamaan sebagai berikut.

$\mathrm{Y}=\alpha+\beta_{1} \mathrm{X}_{1}+\beta_{2} \mathrm{X}_{2}+\mathrm{e}$

$Y=\alpha+\beta_{1} X_{1}+\beta_{2} X_{2}+\beta_{3} Z+\beta_{4}\left(X_{1} Z\right)+\beta_{5}\left(X_{2} Z\right)+e$

Keterangan :

$\mathrm{Y} \quad=$ Profitabilitas (Return On Assets / ROA).

$\alpha \quad=$ Konstanta.

$\mathrm{X}_{1}=$ Leverage.

$\mathrm{X}_{2}=$ Ukuran Perusahan.

$\mathrm{Z}=$ Modal Intelektual.

$\beta_{1}-\beta_{5}=$ Koefisien regresi variabel bebas $X_{1}-X_{5}$

$\mathrm{e}=$ error

\section{HASIL DAN PEMBAHASAN}

Deskripsi variabel penelitian menyampaikan informasi mengenai jumlah pengamatan, nilai minimum, nilai maksimum, nilai rata-rata dan standar deviasi. Hasil statistik deskriptif variabel penelitian ini dapat dilihat pada Tabel 2. 
Tabel 2.

Uji Statistik Deskriptif

\begin{tabular}{lccccl}
\hline & $\mathrm{N}$ & Minimum & Maximum & Mean & Std.Deviation \\
\hline ROA $(\mathrm{Y})$ & 33 & $-0,218$ & 0,073 & $-0,007$ & 0,067 \\
DTA (X1) & 33 & 0,090 & 1,734 & 0,649 & 0,367 \\
Firm Size (X2) & 33 & 31,944 & 1192,901 & 278,825 & 820,921 \\
VAIC (Z) & 33 & $-3,665$ & 4,459 & 1,259 & 2,004 \\
\hline
\end{tabular}

Sumber: Data diolah, 2018

Berdasarkan Tabel 2 nilai ROA terendah sebesar -0,218 dan nilai tertinggi 0,073 dengan rata-rata $-0,007$ dan standar deviasi sebesar 0,067 , ini menunjukkan bahwa variabel profitabilitas memiliki sebaran yang cukup besar karena standar deviasi lebih besar dari rata-rata. Nilai terendah Debt to Total Asset adalah sebesar 0,090 dan nilai tertinggi 1,734 dengan rata-rata 0,649 dan standar deviasi sebesar 0,367, ini menunjukkan bahwa variabel leverage memiliki sebaran yang kecil karena standar deviasi lebih kecil dari rata-rata. Nilai terendah ukuran perusahaan adalah sebesar 31,944 dan nilai tertinggi 1192,901 dengan rata-rata 278,825 dan standar deviasi sebesar 820,921, ini menunjukkan bahwa variabel ukuran perusahaan memiliki sebaran yang cukup besar karena standar deviasi lebih besar dari rata-rata. Nilai terendah variabel modal intelektual adalah sebesar -3,665 dan nilai tertinggi 4,459 dengan rata-rata 1,259 dan standar deviasi sebesar 2,004, ini menunjukkan bahwa variabel modal intelektual memiliki sebaran yang cukup besar karena standar deviasi lebih besar dari rata-rata.

Pengujian data dalam penelitian ini menggunakan 2 regresi yaitu analisis regresi majemuk dan moderated regression analysis (MRA) melalui software SPSS 18.0 for Windows, diperoleh hasil yang ditunjukan pada tabel berikut : 
Tabel 3.

Hasil Analisis Regresi Majemuk

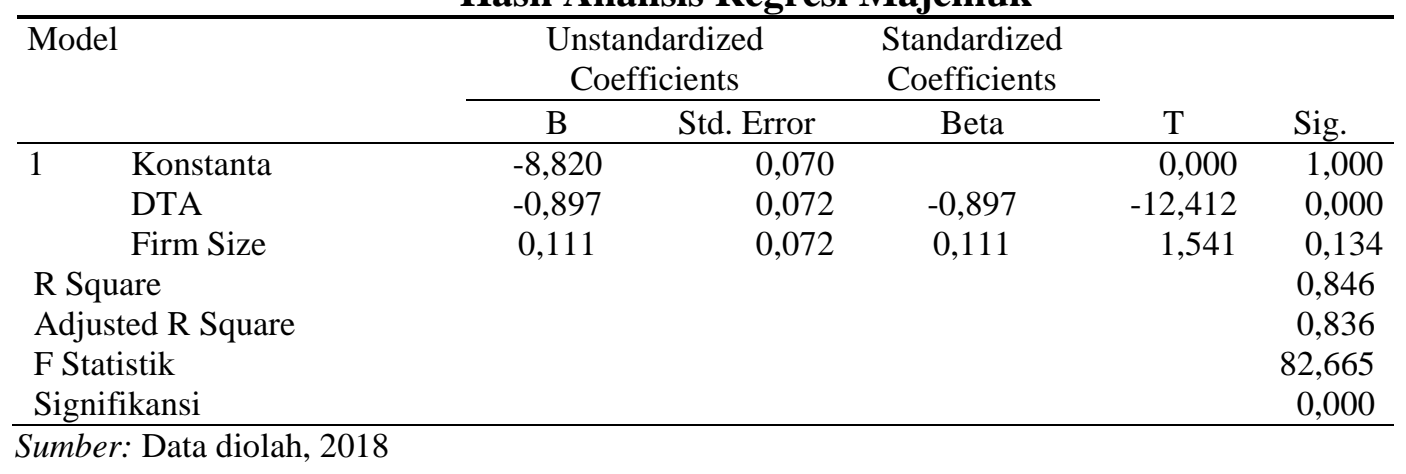

Berdasarkan hasil analisis regresi majemuk seperti yang disajikan pada Tabel 3, maka persamaan strukturalnya adalah sebagai berikut :

$$
Y=-8,820-0,897 X_{1}+0,111 X_{2}+e
$$

Nilai koefisien regresi dari variabel debt to total asset $\left(\mathrm{X}_{1}\right)$ yaitu $-0,897$ dengan signifikansi 0,000 . Hal ini berarti debt to total asset mempunyai pengaruh negatif terhadap profitabilitas perusahaan.

Nilai koefisien regresi dari variabel ukuran perusahaan $\left(\mathrm{X}_{2}\right)$ yaitu 0,111 dengan signikansi 0,134 . Hal ini berarti ukuran perusahaan tidak berpengaruh terhadap profitabilitas perusahaan.

Regresi kedua dalam penelitian ini adalah moderated regression analysis (MRA). Hasil analisis MRA dapat dilihat pada Tabel 4 sebagai berikut : 
Tabel 4.

Hasil Moderated Regression Analysis

\begin{tabular}{|c|c|c|c|c|c|}
\hline & \multicolumn{2}{|c|}{$\begin{array}{c}\text { Unstandardized } \\
\text { Coefficients }\end{array}$} & \multirow{2}{*}{$\begin{array}{c}\begin{array}{c}\text { Standardized } \\
\text { Coefficients }\end{array} \\
\text { Beta } \\
\end{array}$} & \multirow[b]{2}{*}{$\mathrm{T}$} & \multirow[b]{2}{*}{ Sig. } \\
\hline & $\mathrm{B}$ & Std. Error & & & \\
\hline Konstanta & 2,567 & 0,055 & & 0,000 & 1,000 \\
\hline DTA & $-0,658$ & 0,082 & $-0,658$ & $-7,974$ & 0,000 \\
\hline Firm Size & $-0,060$ & 0,116 & $-0,060$ & $-0,517$ & 0,610 \\
\hline VAIC & $-1,692$ & 1,330 & $-1,692$ & $-1,273$ & 0,214 \\
\hline Interaksi X1,Z & 0,271 & 0,160 & 0,271 & 2,559 & 0,016 \\
\hline Interaksi X2,Z & 1,823 & 1,362 & 1,823 & 1,339 & 0,192 \\
\hline R Square & & & & & 0,915 \\
\hline Adjusted R Square & & & & & 0,900 \\
\hline F Statistik & & & & & 58,388 \\
\hline Signifikansi & & & & & 0,000 \\
\hline
\end{tabular}

Sumber: Data diolah, 2019

Berdasarkan hasil moderated regression analysis seperti yang disajikan pada tabel 4, maka persamaan strukturalnya adalah sebagai berikut :

$$
Y=2,567-0,658 X_{1}-0,060 X_{2}-1,692 Z+0,271 X_{1} Z+1,823 X_{2} Z+e
$$

Nilai koefisien regresi variabel debt to total asset $\left(\mathrm{X}_{1}\right)$ bernilai negatif yaitu sebesar $-0,658$ dengan signifikansi 0,000 . Hal ini menunjukkan bahwa debt to total asset mempunyai pengaruh negatif terhadap profitabilitas, jika debt to total asset meningkat maka profitabilitas perusahaan akan menurun sebesar 0,658 dengan asumsi variabel lainnya sama dengan nol.

Nilai koefisien regresi dari variabel ukuran perusahaan $\left(\mathrm{X}_{2}\right)$ bernilai negatif yaitu 0,060 dengan signifikansi 0,610 . Hal ini menunjukkan bahwa ukuran perusahaan tidak berpengaruh terhadap profitabilitas.

Nilai koefisien regresi dari variabel interaksi debt to total asset $\left(\mathrm{X}_{1}\right)$ dengan modal intelektual (Z) bernilai positif yaitu 0,271 dan koefisien regresi debt to total asset $\left(\mathrm{X}_{1}\right)$ bernilai negatif yaitu $-0,658$ dengan tingkat signifikansi 0,016 . Hal ini menunjukaan bahwa modal intelektual memperlemah pengaruh leverage terhadap profitabilitas. 
Nilai koefisien regresi dari variabel interaksi ukuran perusahaan $\left(\mathrm{X}_{2}\right)$ dengan modal intelektual (Z) bernilai positif yaitu 1,823 dan koefisien regresi ukuran perusahaan $\left(\mathrm{X}_{2}\right)$ bernilai negatif yaitu $-0,060$ dengan tingkat signifikansinya 0,192 . Hal ini menunjukkan bahwa modal intelektual tidak memoderasi pengaruh ukuran perusahaan terhadap profitabilitas.

Mengetahui dan mengukur kemampuan model dalam menerangkan variasi variabel independen digunakan koefisien determinasi $\left(\mathrm{R}^{2}\right)$. Peneliti menggunakan nilai adjusted $\mathrm{R}^{2}$ pada saat mengevaluasi yang mana model regresi terbaik, karena tidak seperti $\mathrm{R}^{2}$, nilai adjusted $\mathrm{R}^{2}$ dapat naik atau turun apabila satu variabel independen ditambahkan ke dalam model. Hasil uji memberikan hasil dimana diperoleh besarnya adjusted $\mathrm{R}^{2}$ (koefisien determinasi yang telah disesuaikan) pada analisis regresi majemuk Tabel 3 adalah 0,836. Ini berarti variasi profitabilitas di perusahaan sub sektor tekstil dan garmen yang terdaftar di Bursa Efek Indonesia selama periode tahun 2015-2017 dapat dipengaruhi secara signifikan oleh variabel leverage $\left(\mathrm{X}_{1}\right)$, ukuran perusahaan $\left(\mathrm{X}_{2}\right)$ sebesar 83,6\% sedangkan sisanya sebesar $16,4 \%$ dijelaskan oleh faktor-faktor lain. Pada moderated regression analysis Tabel 4 diperoleh adjusted $\mathrm{R}^{2}$ sebesar 0,900 . Ini berarti variasi profitabilitas di perusahaan sub sektor tekstil dan garmen yang terdaftar di Bursa Efek Indonesia selama periode tahun 2015-2017 dapat dipengaruhi secara signifikan oleh variabel leverage $\left(\mathrm{X}_{1}\right)$, ukuran perusahaan $\left(\mathrm{X}_{2}\right)$, variabel interaksi antara leverage $\left(\mathrm{X}_{1}\right)$ dengan modal intelektual $(\mathrm{Z})$ dan variabel interaksi antara ukuran perusahaan $\left(\mathrm{X}_{2}\right)$ dengan modal intelektual $(\mathrm{Z})$ sebesar $90 \%$ dan sisanya dijelaskan oleh faktor lain. 
Tabel 5.

Hasil Uji Kelayakan Model (Uji F)

\begin{tabular}{llrrrrc}
\hline Model & & Sum of Squares & df & Mean Square & F & Sig. \\
\hline 1 & Regression & 29,291 & 5 & 5,858 & 58,388 & 0,000 \\
& Residual & 2,709 & 27 & 0,100 & &
\end{tabular}

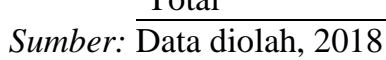

Hasil uji $\mathrm{F}$ menunjukkan bahwa nilai signifikansi $\mathrm{P}$ value 0,000 yang lebih kecil dari $\alpha=0,05$, ini berarti model yang digunakan pada penelitian ini adalah layak. Hasil ini memberikan makna bahwa seluruh variabel independen yaitu leverage $\left(\mathrm{X}_{1}\right)$, ukuran perusahaan $\left(\mathrm{X}_{2}\right)$, modal intelektual $(\mathrm{Z})$, variabel interaksi antara leverage dengan modal intelektual $\left(\mathrm{X}_{1} . \mathrm{Z}\right)$ dan variabel interaksi antara ukuran perusahaan dengan modal intelektual $\left(\mathrm{X}_{2} . \mathrm{Z}\right)$ mampu memprediksi atau menjelaskan fenomena profitabilitas. Hal ini berarti model dapat digunakan untuk analisa lebih lanjut atau dengan kata lain model dapat digunakan untuk memproyeksikan karena hasil goodness of fitnya baik dengan nilai signifikansi $\mathrm{P}$ value 0,000 .

Hipotesis pertama $\left(\mathrm{H}_{1}\right)$ tentang leverage berpengaruh negatif terhadap profitabilitas, dimana hipotesis ini diterima. Hal ini menunjukkan bahwa semakin tinggi tingkat utang, maka beban tetap semakin besar sehingga akan berisiko terhadap kesulitan keuangan. Perusahaan yang menggunakan dana pihak ketiga (utang) maka akan membayar bunga pinjaman. Beban tetap yang timbul akibat penggunaan utang lebih besar daripada manfaat yang diperoleh, sehingga menimbulkan kesulitan keuangan (financial distress). Semakin besar rasio debt to total asset, menunjukkan semakin tinggi risiko perusahaan dan semakin kecil rasio debt to total asset, maka menunjukkan semakin kecil risiko perusahaan. 
Hasil yang diperoleh dalam penelitian ini mendukung teori trade-off. Tradeoff theory merupakan teori yang menjelaskan keseimbangan antara manfaat dan pengorbanan dalam penggunaan utang (Brigham dan Houston, 2011). Teori ini menjelaskan apabila manfaat yang diterima lebih besar daripada pengorbanan, maka perusahaan akan menambah jumlah utang. Sebaliknya, apabila manfaat yang diterima lebih kecil dari pengorbanan, maka perusahaan tidak menambah jumlah utang.

Hasil penelitian yang didapat, konsisten dengan penelitian penelitian yang dilakukan oleh Supardi et al. (2016), yang telah membuktikan bahwa debt to asset ratio berpengaruh negatif terhadap profitabilitas serta Barus \& Leliani (2013), yang menemukan bahwa debt to asset ratio berpengaruh negatif terhadap profitabilitas. Penelitian yang juga dilakukan oleh Riaz (2015), menemukan bahwa debt to asset ratio berpengaruh negatif terhadap profitabilitas. Temuan ini bertentangan dengan penelitian yang dilakukan oleh Ritonga et al. (2014) serta Winahyu \& Mimba (2018), yang menemukan bahwa leverage berpengaruh positif terhadap profitabilitas perusahaan.

Hipotesis kedua $\left(\mathrm{H}_{2}\right)$ tentang ukuran perusahaan berpengaruh positif terhadap profitabilitas, dimana hipotesis ini tidak diterima. Hal ini menunjukkan bahwa perusahaan besar memang memiliki potensi yang besar untuk memperoleh keuntungan yang lebih tinggi, namun perusahaan besar memerlukan banyak biaya untuk memenuhi operasionalnya. Menurut Fachrudin dalam Rezeki (2016), ukuran perusahaan bukan jaminan bahwa perusahaan memiliki kemampuan dalam menghasilkan laba yang baik. 
Hasil yang diperoleh dalam penelitian ini adalah ukuran perusahaan tidak berpengaruh terhadap profitabilitas, hal ini tidak mendukung teori critical resources dalam teori skala ekonomi. Berdasarkan teori critical resources, semakin besar ukuran perusahaan maka kemampuan perusahaan dalam memperoleh laba juga semakin meningkat. Perusahaan yang lebih besar belum tentu menghasilkan laba yang tinggi karena beberapa faktor, sehingga pada perusahaan berskala besar maupun berskala kecil ,hubungan ukuran perusahaan dengan profitabilitas adalah sama atau dengan kata lain ukuran perusahaan tidak berpengaruh terhadap profitabilitas.

Hasil penelitian yang didapat, konsisten dengan penelitian Setiadewi (2015), yang telah membuktikan bahwa ukuran perusahaan tidak berpengaruh terhadap profitabilitas. Penelitian yang dilakukan oleh Rezeki (2016), juga menyebutkan bahwa ukuran perusahaan tidak signifikan terhadap profitabilitas. Temuan ini bertentangan dengan penelitian Niresh dan Velnampy (2014), yang telah membuktikan bahwa ukuran perusahaan berpengaruh positif terhadap profitabilitas. Penelitian yang dilakukan oleh Lee (2009), menemukan bahwa ukuran perusahaan memiliki dampak positif terhadap profitabilitas.

Hipotesis ketiga $\left(\mathrm{H}_{3}\right)$ tentang modal intelektual memperlemah pengaruh leverage terhadap profitabilitas, dimana hipotesis ini diterima. Hal ini menunjukkan apabila pengunaan utang tinggi dan disertai modal intelektual tinggi maka profitabilitas perusahaan tidak serendah sebelumnya atau dengan kata lain profitabilitas perusahaan lebih baik dari sebelumnya. Hal ini dikarenakan adanya pengelolaan utang yang didasarkan atas modal intelektual dapat menimbulkan 
manfaat yang lebih besar dari biaya bunga yang dihasilkan oleh utang tersebut. Organisasi yang didasarkan atas pengetahuan (knowledge management) akan mampu menghasilkan inovasi bisnis dan pengelolaan sumber daya perusahaan dengan efektif dan efisien.

Hasil yang diperoleh pada penelitian ini adalah modal intelektual memperlemah pengaruh leverage terhadap profitabilitas, dengan adanya modal intelektual akan memperkecil dampak negatif dari penggunaan utang (leverage). Hal ini mendukung teori sumber daya (resource-based theory) yang menjelaskan bagaimana perusahaan mengelola organisasi berbasis pengetahuan yaitu dengan modal intelektual. Pengelolaan utang perlu didasarkan atas pengetahuan strategis antara manfaat dan biaya yang timbul (Grant, 1997).

Hipotesis keempat $\left(\mathrm{H}_{4}\right)$ tentang modal intelektual memperkuat pengaruh ukuran perusahaan terhadap profitabilitas, dimana hipotesis ini tidak diterima. Hasil yang diperoleh pada penelitian ini adalah modal intelektual tidak memoderasi pengaruh ukuran perusahaan terhadap profitabilitas. Hal ini tidak mendukung teori sumber daya (resource-based theory) yang menjelaskan bahwa bagaimana perusahaan membangun keunggulan kompetitif yang berkelanjutan dengan menciptakan dan memelihara sumber daya strategis. Pengelolaan modal intelektual secara efektif atau tidak, hubungan ukuran perusahaan dengan profitabilitas adalah sama.

Penelitian ini menghasilkan bukti-bukti empiris yang mengonfirmasi teori trade-off. Bukti empiris yang dihasilkan dari penelitian ini yaitu leverage berpengaruh negatif pada profitabilitas. Hasil penelitian ini mendukung gagasan 
trade-off theory yang menjelaskan keseimbangan antara manfaat dan pengorbanan dalam penggunaan utang (Brigham dan Houston, 2011). Teori ini menjelaskan apabila manfaat yang diterima lebih besar daripada pengorbanan, maka perusahaan akan menambah jumlah utang. Sebaliknya, apabila manfaat yang diterima lebih kecil dari pengorbanan, maka perusahaan tidak menambah jumlah utang. Perusahaan yang kurang profitable akan cenderung menggunakan pendanaan eksternal yang tinggi untuk menjalankan operasionalnya. Ketika perusahaan memakai pendanaan eksternal (utang) dengan jumlah besar, maka perusahaan harus mampu untuk membayar biaya yang timbul seperti biaya bunga pinjaman. Apabila biaya yang ditimbulkan dari adanya penggunaan utang lebih besar dari manfaat yang diperoleh, maka profitabilitas perusahaan akan menurun.

Bukti empiris kedua yang diperoleh yaitu modal intelektual memperlemah pengaruh leverage pada profitabilitas, hal ini mengonfirmasi teori sumber daya (resource-based theory). Teori ini menjelaskan bagaimana perusahaan mengelola organisasi berbasis pengetahuan dengan modal intelektual dalam memberikan value added. Perusahaan yang memiliki utang dalam jumlah besar akan berisiko mengalami kesulitan keuangan karena biaya yang timbul akibat penggunaan utang tersebut tinggi. Ketika perusahaan memiliki rasio utang yang tinggi dan disertai modal intelektual yang tinggi pula, maka profitabilitas perusahaan lebih baik dari sebelumnya atau bahkan profitabilitas menjadi positif.

Hasil penelitian ini dapat digunakan sebagai kontribusi bagi pihak-pihak yang berkepentingan, khususnya perusahaan sub sektor tekstil dan garmen. Perusahaan perlu memperhatikan tingkat penggunaan utang secara efektif dan 
efisien untuk memberikan peluang yang besar dalam meningkatkan hasil usaha, misalkan membeli aset-aset yang produktif. Perusahaan yang bergerak dalam industri tekstil dan garmen ini harus memperhatikan tingkat efisiensi dari penggunaan utang antara biaya yang timbul dengan manfaat yang diperoleh. Pengelolaan modal intelektual yang efektif seperti sumber daya manusia yang handal, penggunaan teknologi yang memadai, dan pengembangan kompetensi sangat penting untuk menunjang kinerja perusahaan sehingga menghasilkan keuntungan yang tinggi.

\section{SIMPULAN}

Leverage berpengaruh negatif terhadap profitabilitas pada perusahaan sub sektor tekstil dan garmen yang terdaftar di BEI tahun 2015-2017. Ukuran perusahaan tidak berpengaruh terhadap profitabilitas pada perusahaan sub sektor tekstil dan garmen yang terdaftar di BEI tahun 2015-2017. Modal intelektual memperlemah pengaruh leverage terhadap profitabilitas pada perusahaan sub sektor tekstil dan garmen yang terdaftar di BEI tahun 2015-2017. Modal intelektual tidak memoderasi pengaruh ukuran perusahaan terhadap profitabilitas pada perusahaan sub sektor tekstil dan garmen yang terdaftar di BEI tahun 2015-2017.

Hasil penelitian yang menunjukan adanya pengaruh leverage dan ukuran perusahaan terhadap profitabilitas dengan modal intelektual sebagai pemoderasi, maka manajemen perusahaan sub sektor tektil dan garmen disarankan untuk tetap atau lebih meningkatkan lagi upaya dalam mengelola modal intelektual yang dimiliki perusahaan untuk meningkatkan profitabilitas perusahaan. 


\section{REFERENSI}

Amato, L., \& Wilder, R. P. (2015). The Effects of Firm Size on Profit Rates in U.S. Manufacturing Southern Economic. Journal University of North Carolina, 181-190.

Ariyanto, T. (2002). Pengaruh Struktur Kepemilikan Terhadap Struktur Modal Perusahaan. Jurnal Manajemen Indonesia, 64-71.

Barus, A. C., \& Leliani. (2013). Analisa Faktor-Faktor yang Mempengaruhi Profitabilitas pada Perusahaan Manufaktur yang Terdaftar di Bursa Efek Indonesia. Jurnal Wira Ekonomi Mikroskil, 3(2), 111-121.

Bhayani, S. J. (2010). Determinan Profitabilitas dalam Industri Semen India: Analisis Ekonomi. Journal of Manajemen Asia Selatan, 6-20.

Chen, C. R., \& Steiner, T. L. (1999). Managerial Ownership and Agency Conflicts: A Nonlinear Simultaneous Equation Analysis of Managerial Ownership, Risk Taking, Debt Policy, and Dividend Policy. Financial Review, 34(1), 119-136. https://doi.org/10.1111/j.1540-6288.1999.tb00448.x

Dwipayana, M. A. T., \& Suaryana, I. G. N. A. (2016). Pengaruh Debt to Asset Ratio, Devidend Payout Ratio,dan Return on Asset Terhadap Nilai Perusahaan. E-Jurnal Akuntansi Universitas Udayana, 17(3), 2008-2035.

Efendi, N. (2013). Analysis of Indonesia Textile Industry Competitiveness in Regulation Theory Perspective By: Nur Efendi, 0-14. Retrieved from http://www.researchgate.net/publication/235766698

Grant, R. M. (1997). The Knowledge-based View of the Firm : Implications for Management Practice. Long Range Planning, 30(3), 450-454.

Halim, A. (2007). Akuntansi Keuangan Daerah (3rd ed.). Jakarta: Rajawali Press.

Harahap, S. (2013). Analisis Kritis Atas Laporan Keuangan (11th ed.). Jakarta: Rajawali Press.

Hartono M., J. (2000). Teori Portofolio dan Analisis Investasi (1st ed.). Yogyakarta: BPFE.

Hurwitz, J., Lines, S., Montgomery, B., \& Schmidt, J. (2002). The linkage between management practices, intangibles performance and stock returns. Journal of Intellectual Capital, 3(1), 51-61. https://doi.org/10.1108/14691930210412845

Idris, M. (2017). RI Masih Impor 70\% Bahan Baku Tekstil, Mayoritas dari China. 
DetikFinance. Retrieved from https://finance.detik.com/industri/d3491064/ri-masih-impor-70-bahan-baku-tekstil-mayoritas-dari-china

Johanson, U., Mårtensson, M., \& Skoog, M. (1999). Measuring and Managing Intangible, Eleven Swedish Qualitative Exploratory Case Studies (1999). IN OECD (Ed.) Internation Symposium on Measuring and Reporitng Intellectual Capital: Experience, Issues and Prospects. https://doi.org/10.1.1.617.459

Kusuma, H. (2005). Size Perusahaan dan Profitabilitas: Kajian Empiris Terhadap Perusahaan Manufaktur yang Terdaftar di Bursa Efek Jakarta. Jurnal Ekonomi Pembangunan, 10(1), 81-93.

Lee, J. (2009). Apakah Ukuran Penting dalam Kinerja Perusahaan? Bukti dari Perusahaan Publik AS. Journal International Economic and Business, 189203.

London, W. of. (1998). Measuring and Valuing Intellectual Capital from Knowledge Management to Knowledge Measurement, Rev. J. Chatzkel. Juornal of Systematic Knowledge Management.

Miyanti, G. A. D. A., \& Putra, I. W. (2010). Pengaruh Tingkat Perputaran Kas, Loan To Deposit Ratio, Tingkat Pertumbuhan Jumlah Nasabah, Spread Management dan Ukuran Perusahaan Pada profitabilitas Koperasi Simpan Pinjam. E-Journal Akuntansi Universitas Udayana, 1(1). Retrieved from https://ojs.unud.ac.id/index.php/Akuntansi/article/view/1923

Myers, S. C., \& Majluf, N. S. (1984). Corporate financing and investment decisions when firms have information that investors do not have. Journal of Financial Economics, 13, 187-221.

Niresh, J. A., \& Velnampy, T. (2014). Firm Size and Profitability: A Study of Listed Manufacturing Firms in Sri Lanka. International Journal of Business and Management, 9(4), 57-64. https://doi.org/10.5539/ijbm.v9n4p57

Peteraf, M. (1993). The Cornerstones of Competitive Advantage: A ResourceBased View. Strategic Management Journal, 14(1), 179-191.

Pratama, I. G. B. A., \& Wiksuana, I. G. B. (2016). Pengaruh Ukuran Perusahaan dan Leverage Terhadap Nilai Perusahaan Dengan Profitabilitas Sebagai Variabel Mediasi. E-Jurnal Manajemen Unud, 5(2), 1338-1367.

Ratnasari, L. (2016). Pengaruh Leverage, Likuiditas dan Ukuran Perusahaan Terhadap Profitabilitas Pada Perusahaan Otomotif di BEI Ilmu Ekonomi Indonesia. Journal Riset Dan Manajemen Sekolah Tinggi, 5(6). 
Riaz, S. (2015). Impact of Capital Structure on Firm's Financial Performance: An Analysis of Chemical Sector of Pakistan. Journal of Poverty, Investment and Development, 12, 85-94.

Ritonga, M., Kertahudi, \& Rahayu, S. M. (2014). Pengaruh Financial Leverage terhadap Profitabilitas (Studi pada Perusahaan Makanan dan Minuman yang Terdaftar pada Bursa Efek Indonesia Periode Tahun 2010-2012). Jurnal Administrasi Bisnis (JAB), 8(2), 1-10.

Sarjana, I. M., Susrusa, K. B., \& Darmawan, D. P. (2013). Analisis Kinerja Keuangan pada Koperasi Serba Usaha di Kabupaten Buleleng. Jurnal Manajemen Agribisni, 1(2), 16-22.

Sawarjuwono, T., \& Kadir, A. P. (2003). Intellectual Capital: Perlakuan, Pengukuran dan Pelaporan (Sebuah Library Research). Jurnal Akuntansi \& Keuangan, 5(1), 35-57.

Serrasqueiro, Z. S., \& Nunes, P. M. (2008). Kinerja dan Ukuran: Bukti Empiris dari UKM Portugis. Journal Business Economics, 195-217.

Stewart, T. A. (2003). Kekayaan Pengetahuan: Modal Intelektual dan Abad Kedua Puluh Satu Organisasi. New York: Doubleday.

Sugiyono. (2017). Metode Penelitian Kuantitatif, Kualitatif, dan R\&D. Bandung: Alfabeta.

Supardi, H., Suratno, H., \& Suyanto. (2016). Pengaruh Current Ratio, Debt to Asset Ratio, Total Asset Turnover dan Inflasi Terhadap Return On Asset. JIAFE (Jurnal Ilmiah Akuntansi Fakultas Ekonomi), 2(2), 16-27.

Wernerfelt, B. (1984). A Resource-Based View of The Firm. Strategic Management Journal, 5(2), 171-180.

Williams, S. M. (2001). Is intellectual capital performance and disclosure practices related? Journal of Intellectual Capital, 2(3), 192-203. https://doi.org/10.1108/14691930110399932

Winahyu, N. W. R., \& Mimba, N. P. S. H. (2018). Intellectual Capital sebagai Pemoderasi Pengaruh Debt to Equity Ratio dan Ukuran Perusahaan pada Profitabilitas. E-Jurnal Akuntansi Universitas Udayana, 23(1), 734-760.

Yuniasih, N. W., Wirama, D. G., \& Badera, I. D. N. (2011). Pengaruh Modal Intelektual pada Kinerja Pasar Perusahaan. Jurnal Ilmiah Akuntansi Dan Bisnis, 1-24. Retrieved from https://ojs.unud.ac.id/index.php/jiab/article/view/2644 